\title{
NEW EU MATRIMONIAL PROPERTY LAW AND THE SITUATION OF POLISH NATIONALS (CITIZENS) $*:$
}

\begin{abstract}
The article discusses the origins, contents and application of the EU Regulation 2016/ 1103 governing the issues of applicable law and court jurisdiction in relation to spouses' property. The author examines the problem cross-border marriages in the EU and the potential applicability of the Regulation to Polish citizen, given that 10 EU Member States, including Poland, have not acceded to that Regulation.
\end{abstract}

\section{Keywords}

European Law - Family Law - International Private Law - law applicable - marital property regime - cross-border marriage

On 29 January 2019 a new EU Regulation No. 2016/1103 governing the issues of applicable law and court jurisdiction in relation to spouses' property matters will finally enter into force. The Regulation will apply as the enhanced cooperation among 18 Member States only, because $10 \mathrm{EU}$

* PHd, Assistant Professor at the Chair of European Union Law, Faculty of Law at Adam Mickiewicz University.

** This article has been completed under the implementation of the scientific task financed, under the decision No DEC-2011/03/B/HS5/01346, by Narodowe Centrum Nauki in Poland. 
Member States, including Poland, have not acceded to that Regulation. In such a situation, will Regulation No. 2016/1103 be applicable to Polish citizens?

\section{CROSS-BORDER MARRIAGES IN THE EU}

The nationals of EU Member States enjoy also EU citizenship in accordance with Article 21 of the Treaty on the Functioning of the European Union. Therefore, they can enjoy the free movement of people, which enables them to travel and settle on the territory of any Member State. All that is required for residence in the host Member State is that the citizen has means of subsistence ${ }^{1}$. Owing to this freedom and European citizenship, European society in the $21^{\text {st }}$ century is highly mobile. That mobility of people not only supports economic development, but also has a social impact including the conclusion of marriages between citizens of different Member States, as well as those from non-Member States) $)^{2}$. The estimated population of the EU - as on 1 January 2016 - amounted to 510.3 million. Young people ( 0 to 14 years old) made up $15.6 \%$ of the EU's population, while persons considered to be of working age (15 to 64 years old) accounted for $65.3 \%$ of the population. Older persons (aged 65 or over) had a $19.2 \%$ share $^{3}$. Owing to the free movement of people and EU citizenship the characteristic of the European Union of the $21^{\text {st }}$ century is a rapid development of legal regulations focused on personal matters. They include the matters of the recognition of professional qualifications (certificates and professional certificates), cases relating to the easier application and cross-border transmission of authentic instruments, such

${ }^{1}$ Judgment of the European Court of Justice (ECJ) of 3 June 1986 in the case C-139/85 R. Kempf v. Staatssecretaris van Justitie (https://eur-lex.europa.eu/legal-content/EN/ TXT/?uri=CELEX\%3A61985CJ0139) and ECJ judgment of 23 March 1982 in the case C-53/81 D. M. Levin v. Staatssecretaris van Justitie (https://eur-lex.europa.eu/legalcontent/EN/TXT/?uri=CELEX\%3A61981CJ0053).

${ }^{2}$ Judgment of the European Court of Justice of 11 July 2002 [in the case] C-60/00 Mary Carpenter v. Secretary of State for the Home Department,

${ }^{3}$ https:/ / ec.europa.eu/eurostat/statistics-explained/index.php?title=Population structure_and_ageing\#The_proportion_of_elderly_people_continues_to_increase 
as civil status acts, notary deeds, and many other authentic instruments ${ }^{4}$. Therefore, the EU regulatory framework concerning EU citizens can be collectively referred to as the EU personal law ${ }^{5}$.

The development of EU law relating to family matters is particularly intensive. Regulations in that regard raise some doubts, since the Treaties have not directly conferred on the European Union legislative power in the field of family legislation'. The Treaties do not apply the terms "family" and "family life" at all". In the Treaty of Lisbon it is only Article 3.3. that

${ }^{4}$ Regulation (EU) 2016/1191 of the European Parliament and of the Council of 6 July 2016 on promoting the free movement of citizens by simplifying the requirements for presenting certain public documents in the European Union and amending Regulation (EU) No 1024/2012 OJ L 200, 26.7.2016, p. 1-136.

Regulation (EU) No 1024/2012 of the European Parliament and of the Council of 25 October 2012 on administrative cooperation through the Internal Market Information System and repealing Commission Decision 2008/49/EC ('the IMI Regulation') Text with EEA relevance, OJ L 316, 14.11.2012, p. 1-11.

5 That term has been developed under EU law by: A. Mączyński, Europejski kontekst rekodyfikacji polskiego prawa prywatnego międzynarodowego [The European context of the recodification of Polish Private International Law] [in:] Finis legis Christus. Księga pamiatkowa dedykowana księdzu profesorowi Wojciechowi Góralskiemu z okazji siedemdziesiątej rocznicy urodzin [Finis legis Christus, a Commemorative Book dedicated to prof. Wojciech Góralski on the 70th anniversary of his birth] vol. 2. Warszawa 2009 p. 1185. M. Sokołowski,, Obywatelstwo UE na tle strategii Europa 2014-2020. Nowy wymiar swobody przeptywu osób w kontekście prawa rodzinnego[EU Citizenship against the background of the Europe 2020 Strategy. The new dimension of the free movement of people in the family law context] [in:] L. Brodowski, D. Kuźniar-Kwiatek (ed.) Księga pamiątkowa prof. Elżbiecie Dyni, [The Commemorative Book dedicated to prof. Elżbieta Dynia] Rzeszów 2015 p. 331 - provides the framework of that term.

${ }^{6}$ R. Lamont, Evaluating European Values: the EU's Approach to European Private International Law, "Journal of Private International Law" 2009, vol. 3, p. 371. P. Mostowik, Kwestie kompetencji Unii Europejskiej oraz warunków pomocniczości i proporcjonalności prawodawstwa unijnego na tle projektów rozporządzeń o jurysdykcji, prawie właściwym i skuteczności zagranicznych orzeczeń w majątkowych sprawach matżeńskich i partnerskich, [The issues of EU competences and the conditions of subsidiairy and proportionality of EU legislation. Remarks on the background of EU draft regulations on jurisdiction, applicable a law and recognition of foreign decisions in financial matters of registered partnership and matrimonial property regimes] “Zeszyty Prawnicze Biura Analiz Sejmowych Kancelarii Sejmu” 2011, vol. 2, pp. 9-41.

${ }^{7} \mathrm{~K}$. Weitz, Europejskie prawo procesowe cywilne - stan obecny i perspektywy dalszego rozwoju, [European civil procedure law - the current state and the development prospects], „Europejski Przegląd Sądowy” 2007, vol. 2, p. 7-9. 
refers to the protection of the rights of the child and the protection of the elderly. The provisions relating to such aspects of family life, the respect for family life, the right to marry, to found a family, the protection of the rights of the child are included in the Charter of Fundamental Rights (Articles 7, 9 and 24 as well as 33).

However, the European Union has legislative power in the area of the so-called "measures concerning family law with cross-border implications" under Article 81 (2-3) of the Treaty on the Functioning of the European Union ${ }^{8}$. However, there are rules which not only authorise the EU law making, but also the taking of other actions by the EU, for example the preparation of annual reports, the so called agendas, for example, on the best interests of the child. However, such actions of EU are not of a legislative nature. ${ }^{9}$ The term "measures concerning family life" should be understood as making private international law rules in the field of judicial procedure, designed for the smooth ruling on crossborder cases by courts of the Member States ${ }^{10}$.

Therefore, over the past 15 years in the EU law a number of regulations governing the conflict-of-law questions of the family law procedure have been issued. The most important one among them is Council Regulation (EC) No. 2201/2003 of 27 November 2003 concerning jurisdiction and the recognition and enforcement of judgments in matrimonial matters and matters of parental responsibility, repealing Regulation (EC)

${ }^{8}$ A. Stępień-Sporek, Wspólne prawo majątkowe małżeńskie dla Unii Europejskiej. Stan integracji - perspektywy. [Common matrimonial property law for the European Union. The current state of integration - prospects], Gdańsk 2014, p. 221-222.

${ }^{9}$ Communication from the Commission to the European Parliament, the Council, the European Economic and Social Committee and the Committee of the Regions. An EU Agenda for the Rights of the Child/* COM/2011/0060 final * . available at: https:/ / eur-lex.europa.eu/legal-content/EN/TXT/?uri=CELEX\%3A52011DC0060

${ }^{10}$ C. Mik, Ochrona rodziny w europejskim prawie wspólnotowym [Protection of the families in European community law], [in:] Prawa rodziny - Materiały krajowej konferencji naukowej [Rights of family - Studies of national scientific conference in Torun Poland], Torun 22-23 X 1998 r., Torun 1999 p. 139; T. Sokołowski, Europejskie prawo rodzinne - pojęcie, zakres, źródta oraz wyktadnia [European family law - the notion, scope. Sources, and interpretation, "Europejski Przegląd Sądowy" 2006, vol. 5, pp. 4-16. A. Stępień-Sporek, Wspólne prawo majątkowe matżeńskie dla Unii Europejskiej. Stan integracji - perspektywy [Common matrimonial property law for the European Union. The current state of integration - prospects], Gdańsk 2014, p. 215-216. 
No. $1347 / 2000^{11}$. That is the regulation which is the foundation of EU legislation in the field of legal procedure ${ }^{12}$. In addition, over the last decade also Council Regulation (EC) No. 4/2009 of 18 December 2008 on jurisdiction, applicable law, and the recognition and enforcement of decisions and cooperation in matters relating to maintenance obligations has been adopted ${ }^{13}$.

In addition, the following Regulation adopted within the framework of the "enhanced cooperation" should be mentioned, i.e. Council Regulation (EU) No. 1259/2010 of 20 December 2010 implementing enhanced cooperation in the area of the law applicable to divorce and legal separation (the so called Rome III) ${ }^{14}$. Additionally, in 2016 under the "enhanced cooperation" two further Regulations No. 2016/1103 and 2016/1104 concerning the issues of applicable law and jurisdiction in connection with the property relations of the spouses and people remaining in a registered partnership were enacted by the Council of the $\mathrm{EU}^{15}$.

Such an extensive development of legal rules for the coordination of cross-border court proceedings in family matters between the nationals of the Member States is caused by the large number of international marriages and families, as well as divorces, and child care and maintenance related cases. This situation is a reflection of the policy of the European Union, which in the current decade, within the framework of the Europe 2020 Strategy, has been aiming at strengthening the legal position and

11 OJ L 338, 23.12.2003, p. 1-29.

12 C. Mik, Międzynarodowe prawo rodzinne Unii Europejskiej na tle ewolucji wspótpracy sadowej w sprawach cywilnych [International family law of European Union against the background of judicial cooperation in civil matters], [in:] L. Ogiegło, W. Popiołek, M. Szpunar [ed.], Rozprawy prawnicze. Księga pamiątkowa Profesora Maksymiliana Pazdana [Legal debates. The Commemorative Book dedicated to prof. Maksymilian Pazdan], Kraków 2005. p. 225 and ff.

13 OJ L 7, 10.1.2009, p. 1-79.

${ }^{14}$ OJ L 343, 29.12.2010, p. 10-16.

15 Council Regulation (EU) 2016/1103 of 24 June 2016 implementing enhanced cooperation in the area of jurisdiction, applicable law, and the recognition and enforcement of decisions in matters of matrimonial property regimes (OJ L 183, 8.7.2016, p. 1-29) and Council Regulation (EU) 2016/1104 of 24 June 2016 implementing enhanced cooperation in the area of jurisdiction, applicable law and the recognition and enforcement of decisions in matters of the property consequences of registered partnerships (OJ L 183, 8.7.2016, p. 30-56). 
protection of its citizens in the area of family law, the labour market, or general improvements in using authentic instruments ${ }^{16}$.

\section{ENHANCED COOPERATION}

A mechanism enabling the overcoming of any possible differences among the Member States is the so-called "enhanced cooperation" which was introduced into EU law in 1999 in the Amsterdam Treaty ${ }^{17}$. Currently, under the Treaty of Lisbon the method of enhanced cooperation is governed by Article 20 of the Treaty on the European Union and Articles 326-334 of the Treaty on the Functioning of the European Union. The enhanced cooperation makes it possible to take legislative action in a group of at least 9 Member States. These actions should aim to protect EU interests and reinforce its integration process (Article 20 (1-2) of the Treaty on the European Union). In addition, these actions must not undermine the internal market or economic, social, and territorial cohesion. What is more, they must not constitute a barrier to neither discrimination in trade between Member States nor must they distort competition between them (Article 326 of the Treaty on Functioning of the European Union). In accordance with the Treaty the possibility of enhanced cooperation on issues related to the fields of EU exclusive competence is excluded..$^{18}$ However, establishing enhanced cooperation within the framework of the common foreign and security policy requires the unanimous authorisation of the Council and the opinion of the High Representative of the Union for Foreign Affairs and Security Policy as well as of the European Commission (Article 329 (2) TFUE).

${ }^{16}$ European Commission's Communication Europe 2020: the European Union strategy for growth and employment; available at: https://eur-lex.europa.eu/legal-content/EN/ LSU/?uri=CELEX\%3A52010DC2020.

${ }^{17}$ E. Piontek, Wzmocniona wspótpraca - otwarty problem [Enhanced cooperation - an open problem] [in:] Quo vadis Europo III? Materiaty Konferencji WPiA UW i UKIE of 12-13 November 2008. [Quo vadis Euope III? Studies of Law conference of 12-13 November 2008.], ed. UKIE Warszawa 2009, pp. 259-261.

18 According the article 20 (1) the first sentence of the Treaty on the European Union and Article 329 (1) the first sentence of the Treaty on the Functioning of the European Union. 
Owing to those limitations, enhanced cooperation is of an exceptional nature rather than a rule. Enhanced cooperation seems to be quite suitable for "cross-border measures in the area of family law". Therefore, EU law governing the issues of cross-border judicial cooperation in family matters could have developed despite the lack of unanimity among the Member States. ${ }^{19}$. Being aware of the fact that in accordance with Article 327 TFEU the introduction of enhanced cooperation among the group of Member States must not impact the competences and obligations of those States which do not participate therein. Hence enhanced cooperation does not affect directly family laws in other States. In addition, the enhanced cooperation is based on the assumption of its "openness". This means that any non-participating Member State is later allowed to join the cooperation which has already been in operation (after fulfilling any possible requirements for participation in it).

That is why: the Commission and the Member States participating in enhanced cooperation shall ensure that they promote participation by as many Member States as possible" (Article 328 (1-2) TFEU).

\section{ORIGINS OF Regulation No. 2016/1103}

In view of the increase in the number of marriages concluded between nationals of different Member States, spouses are not certain as to the law applicable in relation to their common marital property, their acquired gains, or the division of common incomes. In the event of a divorce, there are difficulties in determining the rules of division. All of this is due to the uncertainty of the applicable law in these matters, since the laws relating to both spouses are concerned. What is more, the issue of which court will have jurisdiction over their financial matters, also arouses the concerns of the spouses.

In this situation, the European Commission considered the lack of legal certainty in the field of property rights of international couples as one of the main obstacles faced in everyday life by EU citizens wishing

${ }^{19}$ E. Piontek, Wzmocniona wspótpraca [Enhanced cooperation], p. 267-274. 
to exercise the rights conferred on them by the $\mathrm{EU}^{20}$. The differences between national legal systems are often of an unexpected nature, and they can often have an adverse effect on the property matters of people in international relationships. As early as in 2004 under the Hague Programme, the need to improve the legal situation of the spouses who had concluded marriages with nationals of other Member States, in the area of legal issues related to their mutual property relations, was raised ${ }^{21}$. That issue became the subject of analyses aiming at the preparation, by the European Union, of a draft law governing those issues ${ }^{22}$. In 2006 the European Commission published ${ }^{23}$ a Green Paper on the conflict of laws in matters concerning matrimonial property regimes including the question of jurisdiction and mutual recognition ${ }^{24}$. On the basis of the conclusions included in the Green Paper, in 2009 the drafting of the EU Regulation on the law applicable to the situation of matrimonial property regimes and partnerships was started ${ }^{25}$. The draft regulation related to the Hague Convention on the law applicable to matrimonial property regimes of 14 March 1978 which served as an example for the solutions adopted in the draft. The Hague Convention has been ratified only by France, Luxembourg, and the Netherlands ${ }^{26}$. In addition, the draft was influenced

${ }^{20}$ Report from the Commission to the European Parliament, the Council and the European Economic and Social Committee under Article 25 TFEU] on progress towards effective EU Citizenship 2007-2010 / * COM/2010/0602 final * available at: https:/ / eurlex.europa.eu/legal-content/EN/TXT/?uri=CELEX\%3A52010DC0602

${ }^{21}$ The Hague Programme: strengthening freedom, security, and justice in the European Union OJ 3.3.2005 L 53, p.1. https:/ / eur-lex.europa.eu/legal-content/EN/ TXT /?uri=CELEX\%3A52005XG0303\%2801\%29

${ }_{22}$ W. Pintens, Grundgedanken und Perspektiven einer Europäisierung des Familienund Erbrechts, "FamRZ - Zeitschrift für das gesamte Familienrecht" 2003, p. 329 et seq.; F. Ferrand, [in:] European Family Law in Action ed. K.Boele-Woelki, Antwerp-OxfordPortland 2009 p. 268.

${ }^{23} \operatorname{SEC}(2006)$ 952)/* COM/2006/0400 final, available at: https:/ / eur-lex.europa.eu/ legal-content/EN/TXT/?uri=CELEX\%3A52006DC0400

${ }^{24}$ D. Martiny, Das Grünbuch zum Internationalen Ehegüterrecht, FPR 2008, p. 206.

${ }^{25}$ D. Martiny, Die Kommissionsvorschläge für das internationale Ehegütterrecht sowie für das internationale Güterrecht eingetragener Partnerschaften, IPRax 2011/5, p. 444.

${ }^{26}$ K. Mironowicz, Konwencja haska z dnia 14 marca 1978 r., o prawie właściwym dla małżeńskich ustrojów majątkowych. Zakres zastosowania i metoda regulacji właściwości prawa. [The Hague Convention of 14 March 1978, on the law applicable to matrimonial property regimes. 
by the EU "Stockholm Programme" of 10-11 December 2009 entitled: "An open and secure Europe serving and protecting the citizen". The programme in question focused on enhancing the legal position of the Union's citizens. ${ }^{27}$

At the beginning, it had been assumed that by the end of 2011 a new regulation would be drafted and enacted, but it turned out to be more difficult than expected. The greatest obstacle was not the issues related to the applicable law, but the disputes among the Member States on the grounds of the axiology of family law ${ }^{28}$. They related to the situation of registered partnership, to be covered by the Regulation, since many EU Member States (including Poland) do not provide for such a form of cohabitation ${ }^{29}$. Therefore, two parallel draft Regulations had been prepared which differed slightly from each other, one for the spouses and the other for registered partnerships ${ }^{30}$. Polish law does not provide

The scope of application and the method of regulating applicability of law], „Kwartalnik Prawa Prywatnego" 2000, vol. 3, p. 582.

${ }^{27}$, OJ C 115 of 4.5.2010 available at: https://eur-lex.europa.eu/legal-content/ EN/TXT/?uri=LEGISSUM\%3Aj10034 More detailed information: A. Sapota, Program Sztokholmski zapowiedzia dalszej unifikacji prawa prywatnego w Unii Europejskiej. [The Stockholm Programme as an announcement of further unification of private law in the European Union] Przegląd Sądowy February 2011 p. 100 and ff.

28 A. Mączyński. Konstytucyjne i międzynarodowe uwarunkowania instytucjonalizacji zwiazków homoseksualnych [Constitutional and international conditions of institutionalization of same-sex partnerships] [in:] Zwiazki partnerskie. Debata na temat projektowanych zmian prawnych. [Registered partnerships. Debate on scheduled changes in law]Torun 2013; M. Pilich, Modele regulacji prawnych dotyczace zwiąków partnerskich obowiąujące w krajach europejskich - rys historyczny, [in:] R. Wieruszewski, M. Wyrzykowski, (ed.) Orientacja seksualna i tożsamość ptciowa. Aspekty prawne i społeczne, [Sexual Orientation and Sexual Identity. Legal and Social Aspects] Warszawa 2009, p. 121-123.

${ }^{29}$ M. Pilich, Modele regulacji prawnych dotyczace związków partnerskich obowiąujące w krajach europejskich - rys historyczny, [The models of regulations relating to registered relationships within European countries. An historic outlook] [in:] R. Wieruszewski, M. Wyrzykowski, (ed.) Orientacja seksualna i tożsamość ptciowa. Aspekty prawne i społeczne, [Sexual Orientation and Sexual Identity. Legal and Social Aspects], Warszawa 2009, p. 121-123; P. Mostowik, Brak „strasburskiego" bądź „brukselskiego” obowiązku instytucjonalizacji pożycia osób tej samej ptci oraz regulacja zwiazku partnerskiego kobiety i mężczyzny [A lack of "Strasbourg" or "Luxembourg" obligatory institutionalisation of the same-sex couples cohabitation and regulation of registered relationship between a man and a woman], [in]: Zwiazki partnerskie [Registered Partnerships], ed. M. Andrzejewski, Torun 2013, p. 232 and ff.

${ }^{30} \operatorname{COM}(2011) 127$. 
for registered partnerships. In accordance with Article 18 of the Polish Constitution, marriage is the union of a man and a woman ${ }^{31}$. Polish family law provides that "marriage is a permanent, legal union of a man and a woman, established upon their will as jointly entitled parties for the purpose of cohabitation, the implementation of the best interests of spouses, the best interests of the established family and its social objectives" 32 . In the light of the rules of Polish family law and the Constitution it was not possible for Poland to adopt the new Regulation. What is more, Polish law governs neither informal partnerships, same sex relationships, nor denominational marriages e.g. concluded before the clergy without legally provided form (the so-called "marriage of fact") ${ }^{33}$. From the point of view of Polish law there was the concern of providing equality to the legal positions of registered partnerships and marriages, which is contrary to the Constitution.

In 2011 the European Commission published the draft legal act ${ }^{34}$, which in 2013 was approved by the European Parliament and with a number of amendments was passed to the Council of EU in autumn $2014^{35}$.

Before voting on the Regulation at the Council of EU, a dispute was raised with reference to the fact that the Member States would have to agree to that Regulation's applicability, together with the another Regulation concerning the property matters of registered partnerships. Poland and Hungary, at the December Summit of the Council of EU in 2015 , vetoed the final proposal for the adoption of both Regulations. This determined the need to apply the framework of enhanced cooperation in the following months of $2016^{36}$. In the absence of the possibility of adopting only one of the Regulations by those Member States which do not provide registered partnerships in their legal systems, the so-called enhanced cooperation was relied on. In March 2016 a group of 18 States,

31 A. Mączyński, Der Begriff der Familie in der polnischen Rechtsordnung [in:] N.Witzleb, R.Ellger, P.Mankowski, H. Merkt, O. Remien (ed.) Festschrift für Dieter Martiny zum 70 Geburtstag, Tübingen 2014, p. 1172-1173.

32 T. Smyczyński, Prawo rodzinne i opiekuńcze [Polish Family Law], Warszawa 2001, p. 38.

${ }_{33}$ M. Nazar, Prawo rodzinne [Polish Family Law], Warszawa 2006, p. 87.

${ }^{34}$ COM (2011) 126 final 2011/0059 (CNS).

35 Council Document No. 14611/14 Brussels, 23.10.2014.

${ }^{36}$ It was also the first Polish veto in the history of the Poland's membership of the EU. 
namely Belgium, Bulgaria, the Czech Republic, Cyprus, Germany, Greece, Spain, France, Croatia, Italy, Luxembourg, Malta, the Netherlands, Austria, Portugal, Slovenia, Finland, and Sweden, under the enhanced cooperation, applied to the Council for enacting both Regulations at the meeting held on 24 June $2016^{37}$. Both acts were published on 8 July 2016 as the Council Regulation (EU) 2016/1103 of 24 June 2016 implementing enhanced cooperation in the area of jurisdiction, applicable law, and the recognition and enforcement of decisions in matters of matrimonial property regimes ${ }^{38}$ and Regulation (EU) 2016/1104 of 24 June 2016 implementing enhanced cooperation in the area of jurisdiction, applicable law, and the recognition and enforcement of decisions in matters of the property consequences of registered partnerships ${ }^{39}$.

The adoption of both regulations under the enhanced cooperation limits the scope of their applicability to only those Member States that have acceded thereto. However, that has made it possible finally to adopt the Regulation. An important limitation to the enhanced cooperation is also the fact that the Regulations adopted under enhanced cooperation are not considered as aquis communaire. Therefore, the candidate countries wishing to access the European Union (Article 20 (4) of the Treaty on the European Union) are not bound by the regulations under enhanced cooperation. Outside the framework of enhanced cooperation there is currently a group of 10 States, namely: Denmark, Estonia, Poland, Romania, Hungary, Slovakia, Lithuania, Latvia as well as Great Britain and Ireland. In case of Poland, Polish Private International Law of 2011 is applicable to property matrimonial matters between Polish and foreign nationals domiciled in Poland.

\section{General Characteristics OF REGULATION No. 2016/1103}

Regulation (EC) No. 2016/1106 in addition to the law applicable to matrimonial property regime of spouses covers a broad scope of other

\footnotetext{
37 Session of the Council of EU no 3478 (Document 8115/16) item 2016/0059(CNS).

38 OJ L 183, 8.7.2016, p. 1-29.

39 OJ L 183, 8.7.2016, p. 30-56.
} 
issues ${ }^{40}$. The Regulation also governs court jurisdiction and cross-border recognition and the enforcement of judicial decisions. The basic rules of the new Regulation are included in its extensive preamble, which is of assistance in the interpretation of the Regulation's provisions. The Regulation, similarly to the Hague Convention of 1978, does not include a definition of marriage, since that falls into the competences of respective Member States. Each Member State provides for the possibility of concluding marriages by men and women. Some of the EU Member States also allow for the possibility of entering into such relationships between people of the same sex, and even allow concluding marriages by same sex couples ${ }^{41}$. Therefore, some doubts may arise as to the legal status of such marriages and the possibility of their recognition in other Member States. The Regulation does not force the Member States to recognise the property consequences of marriages concluded by their nationals in a situation when the relationship is not recognised by the law of that Member State as marriage (recital 38 of the preamble in connection with Article 9). In case of doubts as to whether an individual State considers the same sex relationship as marriage, Regulation No. 2016/1103 requires the submission of the case by the court of that State to the courts of another State. It is a condition that these courts recognise whose jurisdiction in that matter is applicable. At the same time, the Regulation requires giving a broad meaning to the term "court" to cover not only courts in the strict sense of the word, but also each State authority e.g. civil servants or notaries exercising judicial functions (recital 29 of the preamble).

40 A. Dutta, Die neue internationale Güterrecht der Europäischen Union; FamRZ 2016/63, p. 1977.

41 A. Mączyński. Konstytucyjne i międzynarodowe uwarunkowania instytucjonalizacji zwiazków homoseksualnych [Constitutional and international conditions of legal institutionalisation of the same-sex relationships] [in:] Zwiazki partnerskie. Debata na temat projektowanych zmian prawnych. [Registered partnerships. Debate on scheduled changes in law], Torun 2013; M. Pilich, Modele regulacji prawnych dotyczace związków partnerskich obowiązujące w krajach europejskichrys historyczny, [The models of regulations relating to registered relationships within European countries. An historic outlook] [in:] R. Wieruszewski, M. Wyrzykowski, (ed.) Orientacja seksualna $i$ tożsamość ptciowa. Aspekty prawne i społeczne, [Sexual Orientation and Sexual Identity. Legal and Social Aspects], Warszawa 2009, pp. 121-123. 
The Regulation defines broadly the concept of the matrimonial property regime of spouses, which refers not only to civil-law (property) aspects arising in connection with the conclusion of the marriage, but also applies to management of property and issues arising as a result of dissolution of marriage. Therefore, this regime does not apply to concluding the spouses' property arrangements only, but also applies to any other situation, including retirement and pension issues or matters of protection of the interests of third parties acting in good faith (recital 18 of the preamble).

The Regulation excludes from its scope maintenance obligations (recital 22 of the preamble), retirement or disability pension matters, (recital 23 of the preamble) and the questions of general legal capacity of the spouses (recital 20 of the preamble). The Regulation also guarantees keeping national competences in the area of registers, e.g. land registers (recital 27 of the preamble).

\section{JURISDICTION AND APPLICABLE LAW IN ACCORDANCE WITH REGULATION NO. 2016/1103}

The new regulation enables the spouses to make the choice of law applicable to their property regime by themselves. The choice of applicable law is limited to the laws designated by the State where either spouses, or one spouse, is resident at the time the agreement is concluded. Alternatively it is possible to choose the law of the State indicated by the nationality of either of the spouses (Article 22).

Another characteristics of choosing applicable law is the possibility of choosing the court to rule on property matters of the spouses. This can be a court of the State whose law the spouses have chosen as applicable to their property regime, or the court of the State of the conclusion of the marriage (Article 7).

In the absence of choice of law by the parties themselves, the law applicable to their matrimonial property regime shall be determined by a number of the so-called objective factors: the spouses' common habitual residence after the conclusion of the marriage, the spouses' common nationality at the time of the conclusion of the marriage, or having the 
closest connection with the respective law at the time of the conclusion of the marriage (Article 26 (1)).

An important innovation is the possibility of withdrawal, by a judicial decision, from the mandatory laws provided for by the Regulation. In such a case, it is the court itself that indicates the law of another State. However, it is necessary that one of the spouses demonstrates that there were other important circumstances which justify the adopting, by the court, of the application of the law of a State other than the State whose law was applicable under the general rules of the Regulation (Article 26 (3)). That provision aims at protecting the rights of a weaker spouse who could have not been aware of the choice of law adverse to that spouse.

Another innovation is the covering, by the applicable law, also of immovable property assets located in another State (Article 21). Typically, immovable property had been subjected to the law of the place of its location (lex rei sitae). However, that does not mean that the State authority over that property is called into question. The principle of the unity of the applicable law relates to the realm of private law between the spouses, but the public law sphere (registers, land registers, tax matters, and administrative matters) still belongs to the authorities of the State in which the immovable property is located ${ }^{42}$.

The Regulation also contains detailed rules on court jurisdiction in connection with the divorce or succession cases of spouses (Articles 4-5). In such event, the court ruling on matters of the succession of a spouse, divorce, or marriage annulment shall also rule on the property matters of the spouses.

As a general rule of jurisdiction, the Regulation indicates the courts of the State in whose territory the spouses are habitually resident or the courts of the State in whose territory the spouses were last habitually resident in so far as one of them still resides there or the court of the State in whose territory the respondent was resident at the time the court was seized or the court of the State of the spouses' common nationality (Article 6).

${ }^{42}$ M. Sokołowski. Intercyza europejska jako metoda umownego ksztattowania matżeńskich ustrojów majątkowych [The European marital agreement as the way of contractual shaping of marriage property regimes], pp. 377-378, Warszawa 2018. 
The Regulation, in order to secure the right to a court also provides for, in Articles 8-12, additional rules for indicating jurisdiction based on the principle of necessary jurisdiction, alternative, and subsidiary jurisdiction in the event of the absence of a court of a State which could rule on the case.

The Regulation provides for provisions protecting the interests of third parties who, in good faith, assumed obligations with spouses. That protection has been based on the principle of due diligence of a party entering into a contract with a spouse. That means that the contracting party itself should endeavour to learn about a fact of the choice of law or the conclusion of the property agreement between spouses (Article 28).

In addition to the applicable law and jurisdiction, Regulation No. 2016/1103 includes the extended system of rules for recognition and enforcement of court decisions and settlements. The Regulation, in its Articles 58-60, governs the transmission of authentic instruments and recognition of court settlements. For the purposes of ongoing court proceedings, all instruments are transmitted as provided by the "service" Regulation No. 1393/2007 of 13 November $2007^{43}$ and therefore are exempted from legalisation or any equivalent formality (Article 4 (4) of the Regulation No. 1393/2007).

The Regulation also governs the rules of the application of provisional and protective measures (Article 53). The possibility of applying all protective measures, provided for in domestic law, is a rule. In conclusion, the Regulation is of a comprehensive nature. Not only does it regulate the issues of the law applicable for the property regime of spouses and court jurisdiction, but it also relates to numerous additional practical issues. For the first time, EU law has covered so extensively, in the sole legal act, so many various issues of the matrimonial regime. However, some doubts could be raised as to whether such an extensive scope of issues falls within the legislative powers of the European Union. Nevertheless, in practice, it is a highly convenient solution, since it makes it possible to include overall issues in one legal act, thus supporting the legal certainty

${ }^{43}$ Regulation (EC) No. 1393/2007 [of the European Parliament and of the Council] of 13 November 2007 on the service in the Member States of judicial and extrajudicial documents in civil or commercial matters (service of documents), and repealing Council Regulation (EC)] No. 1348/2000 (OJ of 10.12.2007 L 324/79). 
and transparency (recital 15 of the preamble). That standpoint has been also expressed in the German doctrine of the conflict-of-laws ${ }^{44}$.

\section{Regulation No. 2016/1103 AND THE SITUATION OF POLISH NATIONALS}

Poland has not accessed the enhanced cooperation applying both Regulations, namely No. 2016/1103 and No. 2016/1104 owing to the impossibility of the recognition of registered partnerships and same sex marriages by Polish law. ${ }^{45}$ Nevertheless, an issue of the impact of Regulation No. 2016/1103 on the legal situation of Polish nationals, living in other EU Member States, arises.

That issue should be dealt with in two variants, firstly from the perspective of the application of Regulation No. 2016/1103 to Polish nationals living abroad, who are subject to the jurisdiction of foreign courts and secondly, with regard to cases ruled on by the Polish courts.

With respect to the first situation, Polish nationals living in another Member State may have their assets or property rights in Poland. If a Polish national marries a national of another Member State abroad, the issue of determination of the law applicable to the matrimonial property regime of the spouses may be subject to Regulation No. 2016/1103 if they are married to the nationals of those EU States which apply the Regulation in question. In such a situation, the courts of those Member States shall rule applying the rules of Regulation No. 2016/1103, which in those States is the applicable law. In this event, the applicable law may be the law applicable at the place of residence of the spouses in accordance with Article 26 of the Regulation. This provision, in the first place, indicates as the law applicable to the matrimonial property regime, the common habitual place of residence of spouses after the conclusion of their marriage. The provision of Article 26 of the Regulation does not contradict Polish law either, namely Article 51(2) of the Polish Private

${ }^{44}$ A. Dutta, Die neue internationale Güterrecht der Europäischen Union; FamRZ 2016/63, p. 1977.

${ }^{45}$ Apart from Poland the Regulation is not applied by: Denmark, Estonia, Ireland, Lithuania, Latvia, Hungary, Romania, Slovenia, or Great Britain. 
International Law, which provides for the place of common domicile or residence of both spouses.

In addition, there is a possibility for spouses to choose the applicable law. Polish nationals entering into marriage abroad with a national of another State participating in enhanced cooperation, can make the choice of the law of that State there, in accordance with Article 22 of the Regulation. In addition, in the event of concluding the marriage in Poland, both spouses may also submit their matrimonial property regime to the domestic law of one of them or of the domicile or habitual residence under the Polish conflict-of-law rule - Article $52 \S 1$ the first sentence of the Polish Private International Law. The choice of a foreign State's law, may at a later time, mean submitting the property regime to the rules of Regulation No. 2016/1103, applicable in that State's law. The Regulation governs issues, such as further amendments to applicable law through subsequent choices of law by the spouses. Thus, there is an opportunity to link that choice to the choice of the court, ruling on property matters of the spouses (Article 7 of the Regulation).

While continuing the analysis of the first aspect, it can be noticed that it is possible for a Polish national to request the Polish court to recognise the decision of a foreign court e.g. in relation to immovable property or other rights located in Poland. In such a situation, it may be necessary for the Polish court to refer to the rules on which the decision by the foreign court which had taken into consideration Regulation No. 2016/1103, was based. The principle of international trade, according to which the courts do not review the substance of the decisions issued by foreign courts, presented to them for recognition in the area of judicial power, should be kept in mind. However, a Polish court should be aware of the legal basis under which the spouses adopted the applicability of foreign law for immovable property in Poland, to prevent Polish courts from unnecessarily refusing, in that respect, the recognition of the contents of a foreign decision for fear of excluding the Polish public law's power over immovable property located in Poland. The Polish court which, owing to the unawareness of Regulation No. 2016/1103, refuses to recognise such a decision - which is not aiming to affect the public power at all - may be at risk of an allegation of unfounded infringement of EU law.

The second aspect of the application of the Regulation applies to situations in which a Polish court within its jurisdiction, rules indepen- 
dently under Polish law. Also in that case, it may be necessary to take into account the rules of Regulation No. 2016/1103 when issuing a decision under Polish law. This situation can occur because of the procedural issues related to the examination of court jurisdiction under Article 1099 of the Code of Civil Procedure. Currently, the Polish courts verify their jurisdiction by themselves. The spouses, one of whom is Polish and who have concluded marriage abroad in the State applying enhanced cooperation, since 27 January 2019, may apply the provisions of that Regulation. Therefore, the spouses may, within the choice of applicable law, choose Polish law for their regime and link that choice to the choice of a Polish court (Article 7.1. of the Regulation). However, the Polish court shall assess its jurisdiction not according to the rules of Regulation No. 2016/1103, but according to the rules of Polish law i.e. the 4th part of the Code of Civil Procedure - rules on international civil procedure. In the absence of grounds for determining Polish jurisdiction (such as the lack of a place of domicile of both spouses in Poland), the risk of refusal to rule on the case of these spouses by a Polish court may arise. Such a situation is undesirable because it carries the risk of finding the decision of the Polish court incompatible with the provision of Article 3 of the Treaty on European Union. Article. 3.2. of the TEU and Article 47 of the Charter of Fundamental Rights guarantee to EU citizens of the right of access to a court and a fair trial. Also in that situation, it can be noted that unawareness of Regulation No. 2016/1103 by Polish courts may lead to violating the general rules of EU law.

Since Poland has not accessed Regulation No. 2016/1103, the general rule assumes the application of Polish Private International Law by the courts, when aiming at the application of a domestic forum conflict-of-laws rule. ${ }^{46}$ However, it should be remembered that Poland is an EU Member State and so participates in a multifaceted legal system. Polish courts are obliged to issue judgments not contradictory to EU law. Therefore, court decisions should not, even unintentionally, produce results contrary to the Treaties and the purposes for which the EU adopts specific regulations, including the Regulation in question. Such a principle, expressed in

${ }^{46}$ M. Pazdan, Prawo prywatne międzynarodowe[Private International Law], Warszawa 2012, p. 80-83; W. Ludwiczak, Międzynarodowe prawo prywatne [Private International Law], Poznań 1996, p. 25-27. 
the Hague and the Stockholm Programmes, is to ensure in all Member States access to justice for EU citizens, including primarily, the clarity and predictability of law and judicial decisions. ${ }^{47}$ As a result, the EU Directives and Regulations should be taken into account by national courts in the interpretation of the national legislation, to prevent issuing decisions in general contrary to the EU legal order and the objectives of the Treaties ${ }^{48}$. Therefore, in case of doubt, the courts of the Member States should submit preliminary questions to the Court of Justice of the European Union ${ }^{49}$. In this context, it is necessary for a Polish court to get familiar with the rules of Regulation No. 2016/1103, before issuing a decision on a matrimonial property case of a Polish national, if the EU Regulation is covered by the content of that case.

Although the Regulation is not applicable on the territory of Poland and the Polish courts apply their own national conflict-of-law rules - the act Private International Law of 2011 - it does not follow automatically that the Polish courts will not face having to take into account the new Regulation. Firstly, in accordance with Article 8 (of the Private International Law) occasionally Polish courts, in order to avoid the consequences in which their decisions would be incompatible with the law of the State in which their results are produced, should apply, or take into account, also foreign law $^{50}$. This assumption applies, in principle, to

47 The Hague Programme: [Strengthening Freedom, Security and Justice in the European Union item 3] „Wzmacnianie wymiaru sprawiedliwości” Strengthening justice. Available at: https://eur-lex.europa.eu/legal-content/EN/TXT/?uri=CELEX\% 3A52005XG0303\%2801\%29].

${ }^{48}$ K. Kowalik-Bańczyk, Zasada skuteczności prawa wspólnotowego[Effet utile - the rule of direct utility of European community law]. The judgment in the case 14/83 von Colson and Kamann v. Nordrhein-Westfallen, "Europejski Przegląd Sądowy" 2006, vol. 5, pp. 55-58.

49 Judgments: C-283/81 C.I.L.F.I.T. v. Ministry of Health [1982] ECR 3415 and C-314/85 Photo Frost v. Hauptzollamt Lübeck Ost [1987] ECR 4199. More on the issue of the obligation to submit the preliminary questions by domestic courts, see: A. Kastelik-Smaza, Konsekwencje naruszenia obowiazku skierowania pytania prejudycjalnego do ETS [The consequences of disobeying of preliminary rulings by the European Court of Justice], "Europejski Przegląd Sądowy" 2007, vol. 2, p. 24-31.

${ }_{50}$ P. Rylski, Stwierdzenie treści prawa obcego i obcej praktyki sądowej w polskim postępowaniu cywilnym [The acknowledgment of foreign law and judicial practices in Polish procedural law], [in:] J. Gudowski, K. Weitz (ed.) Aurea praxis aurea theoria. Księga Pamiatkowa ku czci 
substantive law. The Regulation contains the rules based on the merits of substantive law, for example the choice of the applicable law. Many of those rules are covered by the preamble of the Regulation. Moreover, Regulation No. 2016/1103, in addition to the conflict-of-law rules of applicable law, covers a set of procedural conflict-of-law rules relating to the transmission of instruments, recognition, and enforcement of court decisions and settlements, protection of the good faith of third parties, and the issues of the registers' applicability. All that makes Regulation No. 2016/1103 a comprehensive legal instrument (of a legal - the conflict of law, procedural and substantive nature). Owing to this characteristic, the issue arises of taking into consideration the content of that Regulation, as the so called foreign law, rather than directly the rules of Regulation No. 2016/1103 by Polish courts ${ }^{51}$. Failure to apply foreign law, contrary to the conflict-of-law rule, is an error of the court's adjudication (error in law) which constitutes in itself an autonomous appeal condition ${ }^{52}$.

Finally, the issue referred to above, of the integrity of national public authorities in relation to immovable property, should also be noted. This includes the need to take into account Regulation No. 2016/1103 in relation to the national registers, in view of the principle, expressed by the Regulation in recital 27 of the preamble, that the law of the Member State in which the register is kept (for immovable property the lex rei sitae), should specify the legal conditions and the method of recording as well as the authorities entitled to keep thereof. It is only the law of the Member State that determines the nature of recording in registers and the effects of the recording a right in a register (recital 28 of the preamble).

Therefore, the Polish land registry courts - to which Polish nationals concluding marriages with foreigners, subjected to a foreign matrimonial property regime, apply - should be prepared for a situation of recordings relating to legal transactions of spouses performed in connection with the

Profesora Tadeusza Erecińskiego. T. I [Aurea praxis aurea theoria. The Commemorative Book dedicated to Professor Tadeusz Ereciński. Vol.I] Warszawa 2011, p. 1305 et seq.

${ }^{51}$ W. Ludwiczak, Prawo prywatne międzynarodowe 1996 p. 127-129, similarly: M. Pazdan, Prawo prywatne międzynarodowe, zarys wyktadu[Private International Law, the lecture outline], Warszawa 2012, p. 84.

${ }_{52}$ T. Ereciński, Prawo obce w sądowym postępowaniu cywilnym [Foreign law in civil judicial proceedings], Warszawa 1981, pp. 185-187 and 190-191. 
provisions of the matrimonial agreements of spouses, in particular, if the matrimonial agreement relates to immovable property located in Poland.

\section{FINAL CONSIDERATIONS}

The new EU marital property law ${ }^{53}$ affects not only the legal position of nationals of those States that have adopted Regulation No. 2016/1103 into their law, but also the position of nationals of the other Member States. However, this is admittedly an indirect interaction that causes the "infiltration" of the effects of that regulation into their legal framework. Thus, it is necessary to be acquainted with the provisions of the Regulation and in particular, its specific innovations, such as the possibility of choosing the law of any State, not only the Member State, the possibility of choosing the court, and the need to rule on the spouses' property matters in the forum of the court indicated by the spouses themselves when making the choice of law.

Regulation (EC) No. 2016/1103 contains a number of provisions to facilitate the circulation of authentic instruments and the recognition and enforcement of decisions, which significantly facilitate, in practice, legal transactions, especially the recognition and transmission of documents which are the matrimonial property agreements. With regard to Poland and other States not participating in that Regulation, the general rules for the transfer, recognition, and enforcement of decisions, covered by Regulation No. 2201/2003, are still applicable.

In conclusion, the view could be expressed that although the new Regulation No. 2016/1103 is not directly applicable in Poland, it will be able to influence the legal situation of Polish nationals abroad. Therefore,

${ }^{53}$ Such a term for new EU legal instruments is proposed by the legal doctrine in Poland: A. Stępień-Sporek, Wspólne prawo majątkowe małżeńskie dla Unii Europejskiej. Stan integracji - perspektywy [Common matrimonial property law for the European Union. The current state of integration - prospects]. Gdańsk 2014. Similarly in German legal writings: A.Dutta, Die neue internationale Güterrecht der Europäischen Union; FamRZ 2016/63, p. 1977. In the Polish doctrine the term "European Marital Agreement" is proposed: M. Sokołowski, Intercyza europejska jako metoda umownego kształtowania matżeńskich ustrojów majątkowych [The European marital agreement as the way of contractual shaping of marriage property regimes], Warszawa 2018. 
penetration of the effects of this Regulation into the Polish legal area cannot be excluded. It is also worth noting that there are no significant differences between the laws applicable under Regulation No. 2016/1103, and the laws under the Polish act - Private International Law of 2011. Therefore, the situation of Polish nationals in the scope of applicable law available to them, in fact, has not significantly changed.

On the other hand, in addition to the applicable law and court jurisdiction, Regulation No. 2016/1103 also governs many other issues that have a comprehensive effect on the overall legal position of spouses. For example, that made it possible to rule, before one court, on the property issues related to divorce or succession (Article 4 and Article 5), and it governs the issues of recognition and enforcement of court decisions (Article 36 and Article 47) and settlements (Article 60). The Regulation simplifies the rules for circulation and recognition of authentic instruments related to the matrimonial property regime of spouses (Article 58). We shall live and learn whether Polish accession to the enhanced cooperation within the framework of Regulation No. 2016/1103 could be appropriate. Time will show how it operates in the EU's day to day practice. In accordance with Article 68 (1) in January 2027, and therefore within the next 10 years, the European Commission has to present a report on the application of that Regulation, when necessary, accompanied by the suggestions to amend it. It can be assumed that the 8 -year period of that regulation's application (the Regulation will enter into force on 29 January 2019), in practice, will allow for a meaningful assessment of the relevance of the solutions adopted therein. 